\title{
Determinants of Large Shifts in Official Development Aid Allocation by Major Countries
}

\author{
Njato Rabehajaina1, Kodjovi Assoe ${ }^{2}$, Komlan Sedzro ${ }^{2}$ \\ ${ }^{1}$ Doctoral School, Catholic University of Madagascar, Antananarivo, Madagascar \\ ${ }^{2}$ School of Management, University of Quebec in Montreal, Montreal, Canada \\ Email: njato@mail.com, assoe.kodjovi@uqam.ca, sedzro.k@uqam.ca
}

How to cite this paper: Rabehajaina, N. Assoe, K., \& Sedzro, K. (2022). Determinants of Large Shifts in Official Development Aid Allocation by Major Countries. Theoretical Economics Letters, 12, 172-194. https://doi.org/10.4236/tel.2022.121010

Received: December 13, 2021

Accepted: February 5, 2022

Published: February 8, 2022

Copyright (c) 2022 by author(s) and Scientific Research Publishing Inc. This work is licensed under the Creative Commons Attribution International License (CC BY 4.0).

http://creativecommons.org/licenses/by/4.0/

(c) (i) Open Access

\begin{abstract}
This study provides a comparative analysis of the main determinants of large shifts in aid allocation by major donors, namely China, France, the United Kingdom, and the United States. In contrast to continuing assistance, significant year-over-year variation of allocated aid to a given recipient is considered a new and deliberate decision by the donors. Using a version of quantile regression to account for heterogeneity in the characteristics of aid recipients, we show that significant differences exist in the aid allocation strategies of the major donors. There is no conditionality attached to Chinese aid, while self-economic interests and corruption levels at home and in the recipient countries determine aid allocated by France and the U.K. to their former colonies. In addition, recipient needs affect aid from France, the U.K., and the U.S. Over the 2000-2014 period, there is no significant change in the determinants of aid allocation by China in response to various criticisms of its approach. Confronted with the growing influence of emerging donors such as China, the three major traditional donors seem to adjust their aid allocation policy towards their own economic interests.
\end{abstract}

\section{Keywords}

Aid Allocation, Official Development Assistance, China, France, United Kingdom, United States, Recipient Countries

\section{Introduction}

The Development Assistance Committee (DAC)'s stated goal is to contribute to sustainable development, help developing countries emerge from poverty, and ensure a future in which no country will depend on external aid. Several recommendations have been made to achieve these objectives, including setting a 
ratio of $0.7 \%$ of the gross national income (GNI) that developed countries should earmark for aid, under a United Nations Resolution in 1970. The OECD statistics indicate that the total amount of aid more than quadrupled between 2000 and 2016, from 49.12 billion to 216.43 billion in constant 2010 U.S. dollars ${ }^{1}$. Aid from DAC member countries has increased between 2000 and 2016, from 35.72 billion to 137.05 billion in constant 2010 U.S. dollars. Despite this increase in ODA from DAC member countries, the growth remains very low compared to the growth of aid from emerging, non-DAC member countries. In fact, aid from non-DAC member countries shot up from 15.38 million in 2001 to 14.65 billion in 2016 in constant 2010 U.S. dollars. Among the emerging donors, especially Brazil, Russia, India, China, and South Africa (BRICS) countries, China has overtaken India and become the largest donor (Asmus et al., 2017).

It is argued that donor countries use bilateral aid as a means of domination over recipient countries. For example, Neumayer (2003a) and Bermeo (2017) state that some donors grant more aid to their former colonies to maintain their influence. France and the United Kingdom are the former colonial powers most criticized in this regard (Alesina \& Dollar, 2000; Zanger, 2000). Woods (2008) maintains that Chinese aid is more appealing to and more appreciated by recipient countries than aid from other countries, particularly DAC member donors, as the conditions imposed on recipients by major donors are deemed ineffective. In addition, emerging donors such as China advocate for the sovereignty of recipient countries and for not intruding in their domestic politics, which makes their aid more appealing to many recipients. Chun et al. (2010) reveal that traditional donors want to respond to the expansion of Chinese aid, which now impacts almost every region of the world. Therefore, the purpose of this paper is to investigate how an emerging donor such as China allocates its aid and how traditional donors are adjusting their aid allocation strategies in recent years in response to China's growing influence.

As aid from non-DAC countries is growing faster than that from DAC members who are looking for ways to maintain their influence, our research questions can be framed as follows: what are the factors that determine the provision of official development assistance (ODA) by emerging and traditional major donors? To what extent do the approaches used by main traditional donors differ from those of emerging donors? Is there a convergence of the determinants of aid allocation, either through shifts over time in the factors used by traditional donors in response to emerging donors' approaches or through the adoption of conventional criteria by emerging donors? By answering these questions, this paper contributes to the literature on ODA allocation criteria, shedding new light on major donors' aid allocation determinants.

Specifically, we propose to re-examine the factors determining significant variations in the allocation of aid to specific recipients by four major donor countries: 1) China, which is, among emerging donors, the one that is giving the most aid in terms of volume, all beneficiaries combined (Asmus et al., 2017);2) ${ }^{1}$ See https://stats.oecd.org/. 
the United States as one of the major traditional donors providing over $25 \%$ of all DAC aid between 2000 and 2016; 3) France and 4) the United Kingdom that are the two colonial powers challenged in their traditional influence on their former colonies. ODA to a recipient country is generally a multi-year commitment by the donor. Previous studies on the determinant of aid allocation do not distinguish between ongoing aid commitment flows and a new decision by a donor to substantially increase or decrease the allocated amount. We postulate herein that a substantial year-over-year change in ODA flows can only result from a new and deliberate decision by the donor that considers the characteristics of the recipient and all other available information. We hypothesize that a year-over-year variation of $25 \%$ or more in the volume of aid is reflective of a new decision and a significant shift in the allocated aid.

We investigate whether the determinants of aid allocation have changed over time, both for China and for the three traditional donors (France, the U.K., and the U.S.). There is a lack of comprehensive and granular data on Chinese ODA. We take advantage of the new dataset introduced by Dreher et al. (2017) that includes development aid and other forms of government financing from China over the 2000-2014 period. By relying on the version of quantile regression that corrects for heteroscedasticity, we use a robust econometric approach to deal with the outliers observed during the sample period.

The rest of the paper is organized as follows: Section 2 reviews the aid allocation literature relevant to our analysis. We describe our variables and data in Section 3, followed by the methodology in Section 4. Section 5 presents our main results and the robustness checks, and we conclude in Section 6 .

\section{Literature Review}

Several researchers have analyzed the determinants of ODA. The literature categorizes the variables influencing aid allocation into four broad types, two of them related to the aid recipients and the other two to the donors: recipient needs and recipient merits; and donor interests and donor institutional quality. Recipient needs are proposed as a criterion for aid allocation by Dollar and Levin (2006), Hoeffler and Outram (2008), Feeny and McGillivray (2008), amongst others, who argue that aid should target the poorest and most needy countries. Social indicators, poverty level, and per capita revenue provide information on this factor. The merits of the recipient are also considered as criteria for the allocation of aid by some donors who refer to them as a discriminatory factor between the poorest beneficiaries. Claessens et al. (2009) find that starting in the 1990s, bilateral aid has been more aligned with the level of poverty and the quality of the institutional environment in beneficiary countries. Burnside and Dollar (2004) confirm that aid is more effective when allocated according to the recipients' merits, such as institutional soundness criteria and the level of democracy. While Miller (2014) recommends that recipient merits be considered by donors when allocating aid for development and for biodiversity conservation, 
Hoeffler and Outram (2011) reveal that recipient merit matters little to many donors for whom the beneficiaries' needs and the donor's own interests play a significant role in the aid allocation decision. Donors differ in terms of how much their own interests' impact their aid allocation criteria. According to Berthélemy (2006), the least self-interested donors take into consideration the recipients' needs in combination with their merits; for the most self-interested donors, their own political and economic interests dictate their aid allocation decisions. Some authors (Vreeland \& Dreher, 2014; Alesina \& Dollar, 2000) assert that Western donors' own interests have the greatest impact on their aid decisions. Clist (2011) states that these interests vary widely and may include religion, culture, history, geography, and trade. According to Bermeo (2017), a shared colonial past and a common language allow historical bonds to develop to the extent that donors provide more aid to their former colonies to retain influence. Evidence is provided by Zanger (2000), who shows that France uses this status to preserve ties with its former colonies, and by Carey (2007), who proves that former French and British colonies get twice as much aid in volume. Strömberg (2007) underscores the importance of a shared official language, pointing out that donors give more aid to beneficiaries that speak the same official language. According to Lundsgaarde et al. (2010), having a common administrative language increases donor confidence about transparency and decreases the various costs involved in distributing aid. Emphasizing the potential self-interest of donors, Betzold and Weiler (2018) state that donor-recipient trade relation has a considerable influence on the amount of aid received by a beneficiary. Wagner (2003) finds that donors tie $50 \%$ of their foreign aid to exports, and Younas (2008) shows that the exports of products and services from a donor to a recipient increase at the same rate as the flow of aid. The fourth type of variable influencing aid allocation decisions is the donors' institutional quality. Szent-Iványi (2012), Chong and Gradstein (2011), and Schudel (2008) demonstrate that the donor's level of corruption affects the volume of aid received by beneficiaries. They show that donor countries with low corruption rates tend to allocate their aid to recipients with a low level of corruption.

Emerging donors and especially China are now playing a much more significant role, and their volume of aid has grown significantly. As stated by Paczynska (2020), emerging donors frame their assistance in language that prioritizes solidarity, sharing of development experiences, and mutual support, in contrast to traditional DAC countries, especially Western donors. According to Dreher et al. (2018), recipient countries are hoping that non-Western donors will exhibit different behavior than the self-interest shown by Western donors. However, Dreher et al. (2013) show that aid is allocated by emerging and traditional donors according to the same principles. In contrast, Dreher et al. (2011) reveal that emerging donors attach more importance to geographical proximity and to disasters, and hardly consider the needs and merits of recipients or their own trade interests. 
Among the emerging donors, China is the leader in terms of aid flows (Asmus et al., 2017). There are several similarities between aid from China and from traditional donors. For instance, Goldstein et al. (2006) state that China uses its aid program as a tool of economic and political influence. Kragelund (2008) argues that Chinese aid is linked to other financial flows, such as trade and investment, and that China has used aid to expand its diplomatic relations in various regions, notably Africa. However, the aid provided by China is different enough from that of older donors that it is more appealing to recipients. Kragelund (2008) and Manning (2006) review the commitments made by China at the Millennium Summit in terms of offering several aid options, promising the equality and mutual benefit of aid, as well as non-interfering in the internal affairs of recipient countries. Broich (2017) points out that China does not consider the recipients' institutional quality, and Woods (2008) suggests that there is no conditionality to Chinese aid.

This literature review shows that there is no consensus on the determinants of aid allocation. Moreover, the question of whether the determinants of aid allocated by emerging donors such as China differ from those of traditional donors remains open and is addressed in this paper.

\section{Data and Justification of Variables}

\subsection{Dependent Variable}

The primary measure of official development assistance (ODA) used in this paper is the total committed aid by each donor to the selected recipients. We follow Berthélemy and Tichit (2004) who advocate using committed aid since it accounts for the donor's actual decision and its intent, as well as the beneficiaries' desire and administrative capacity to obtain the assistance. Since the exact decision date is usually unknown, we assume that a sizeable year-over-year variation in the ODA is a well-thought-out decision by the donor based on available information on the recipient countries. In our base analysis, we are focusing on the new aid commitment or disengagement by retaining only the years where there is a year-over-year variation of at least $25 \%$ of a donor's ODA to a given recipient.

Using the total aid is proposed by Schneider and Tobin (2013) and Amusa et al. (2016), according to whom this metric is used in practice and allows donors to roughly rank beneficiaries at the time of the commitment to allocate aid. For robustness check, we will later change the dependent variable to committed aid per capita (instead of the total committed aid), in line with Annen and Kosempel (2009) and Clist (2009), who suggested that the per capita data eliminates the bias against less-populated countries.

In this study, we examine the determinants of the ODA committed by each donor to its recipients over the 2000-2014 period. We do so for Chinese aid to 15 recipient countries as identified by Dreher et al. (2017), for American aid to 45 countries with English as their official language, and for the British and French 
aid to 45 and 33 former colonies, respectively. There was no comprehensive database on Chinese aid. Dreher et al. (2017) introduce a new dataset on Chinese foreign aid and other forms of government financing over the 2000-2014 period. We rely on their dataset and keep the 15 recipient countries for which ODA data are available through the whole fifteen-year period. For France, the U.K., and the U.S., the ODA data in current U.S. dollars are taken from the OECD database and converted into constant 2010 U.S. dollars using the price index from the World Bank database ${ }^{2}$. OECD statistics are the source of official data on aid reported by members of the OECD Development Assistance Committee.

\subsection{Explanatory Variables}

We rely on the literature reviewed in the previous section to select the main determinants of aid allocation in each of the four categories: the recipient's needs, the recipient's merits, the donor interests, and the donor quality.

We use the gross domestic product (GDP) as a proxy variable for recipient needs, as in Amusa et al. (2016), Koch et al. (2009), Neumayer (2003b), amongst others. For instance, Neumayer (2003b) states that this variable is sufficient for capturing recipient needs since it is highly correlated with physical needs, including the actual standard of living and the quality of healthcare and education in recipient countries. According to Amusa et al. (2016), the GDP also measures the absorptive capacity of aid by the beneficiaries. The GDP data are taken from the World Bank database and are given in constant 2010 U.S. dollars ${ }^{3}$. As in Nunnenkamp and Thiele (2006), we expect that the recipients' needs will influence aid allocation decisions and that the greater is the beneficiary's need, the more aid it will receive.

Alesina and Dollar (2000) suggest the use of the recipients' governance quality as a metric for the recipient's merits. These authors state that there must be a link between the recipients' quality of governance and aid allocation. Larmour (2017) shows that donors have a great deal of influence on recipients that are dependent on aid in terms of adopting sound governance and desired reforms. We expect that donors will allocate more aid to recipients with good governance practices, as in Weiler et al. (2018). To measure good governance, we choose corruption and democracy among the proxy variables. We use the Bayesian Corruption Index (BCI) introduced by Standaert (2015) as a proxy variable for corruption ${ }^{4}$. The BCI ranges from 0 (absolutely no corruption) to 100 (pervasive corruption). For the democracy variable, we rely on the Freedom House indicator of the level of democracy. The democracy indicator takes the value of 1 if there is no freedom, 2 for partial freedom, and 3 for total freedom.

We focus on two donor interests, namely the commercial interest and the

${ }^{2}$ See https://stats.oecd.org/ and https://databank.worldbank.org/.

${ }^{3}$ See https://databank.worldbank.org/source/world-development-indicators.

${ }^{4}$ See https://users.ugent.be/ sastanda/BCI/BCI.html. The BCI index is different from other known measures of corruption: an increase in the index corresponds to a rise in the level of corruption.

${ }^{5}$ See https://freedomhouse.org/report/freedom-world. 
proximity interest. As in Clist (2011), we select exports from a donor's country to the recipient as the proxy variable for the commercial interest of the donor. Since the volume of export can capture the economic interest of the donor, we anticipate that the higher the export to a given recipient country, the higher the aid. Export data are taken from the International Monetary Fund (IMF) database and are expressed in Free On Board (FOB) constant 2010 U.S. dollar terms ${ }^{6}$. We also include the proximity interests of the donor by using the geographic distance between the donor and the recipients. According to Dietrich (2013) and Strömberg (2007), increased distance weakens inter-government relationships between donors and beneficiaries so that countries located farther away receive less aid than those that are nearby. We use the approach proposed by Mayer and Zignago (2011), who measure distance via the number of kilometers between the donor's and the recipient's capital city. Data for this variable are taken from CEPII's GeoDist database ${ }^{7}$.

For the fourth class of explanatory variables, we use the corruption level as a metric of the donor country's institutional quality (Rayp \& Standaert, 2017). Chong and Gradstein (2011) show that aid is negatively and significantly correlated with the donor's corruption level. Based on this result, we expect that the amount of aid allocated by a donor will decrease as its corruption level increases. As for the recipient countries, we also use the Bayesian Corruption Index (BCI) for the donor countries.

\subsection{Control Variables}

We select four control variables: the population size of the recipient country, the existence of civil conflict in the recipient country, the existence/nonexistence of terrorist acts in the recipient country, and the ratio of the donor's GDP to the recipients. Berthélemy (2006) shows that adding the population-size variable prevents the proportion effect or the positive relationship between size and aid. Since Younas (2008) points to the decrease of aid's marginal impact with an increase of the recipient country's population size, we anticipate that aid and population size will increase simultaneously. Population data come from the World Bank database.

We also control for the security in the recipient countries, following Crost et al. (2014), who state that donors have been targeting countries experiencing more conflict when allocating aid in recent years. Consequently, we expect an increase in the amount of aid allocated to recipient countries with civil conflicts. An indicator of the existence of civil conflicts is used, taking a value of 1 if there is a civil conflict during a year $\mathrm{t}$, and 0 otherwise. Data are drawn from the Peace Research Institute Oslo (PRIO) $)^{8}$.

We also consider the existence of terrorist actions in the recipient countries,

${ }^{6}$ See https://data.imf.org/regular.aspx?key=61013712.

${ }^{7}$ Source: http://www.cepii.fr/cepii/fr/bdd_modele/presentation.asp?id=6.

${ }^{8}$ See https://www.prio.org/Data/Armed-Conflict/UCDP-PRIO/. 
in line with Azam and Delacroix (2006), who demonstrate that an increase in terrorist activity in each country increases the amount of aid it receives. According to Dreher and Fuchs (2011), several DAC countries have been increasing aid to fight terrorism since the September 11, 2001 attacks in the U.S. Consequently, we expect that the existence of an act of terrorism will be positively correlated with the amount of aid. An indicator of the presence of terrorist action has a value of 1 if a terrorist act has taken place during a year $t$ in a recipient country, and 0 otherwise. Data are extracted from the Global Terrorism Database ${ }^{9}$.

The fourth control variable is a measure of the level of development of the donor country relative to the recipient. We assume that the donor's GDP must be higher than the recipient's, and we take the ratio of the donor's GDP to the recipients to control our model. We anticipate that the more significant the gap between the donor's and the recipient's GDPs, the more aid will be allocated to that recipient.

\section{Methodology}

The following econometric model is used to find out what factors influence aid allocation by the U.S. to countries with English as their official language, by the U.K. and France to their former colonies, and by China to its primary aid recipients:

$$
\begin{aligned}
O D A_{i, j, t}= & \alpha_{i}+\beta_{1} G D P_{i, t-2}+\beta_{2} E X P_{j, i, t-2}+\beta_{3} D I S T_{j, i}+\beta_{4} B C I_{i, t-2} \\
& +\beta_{5} D E M_{i, t-2}+\beta_{6} B C I_{j, t-2}+\Upsilon X_{i, t-2}+\varepsilon_{i, t}
\end{aligned}
$$

where $O D A_{i, j, t}$ is the logarithm of 1 plus the total aid committed to recipient $i$ by donor $j$ in year $t ; \alpha_{i}$ is the individual fixed effect of each recipient $i$; $G D P_{i, t-2}$ is the logarithm of the gross domestic product of recipient $i$ at time $t-$ 2 ; $E X P_{j, i, t-2}$ is the logarithm of 1 plus the exports by donor $j$ to recipient $i$ at time $t-2 ; D I S T_{j, i}$ is the logarithm of the distance between the capital of donor $j$ and recipient $i$ in kilometers; $B C I_{i, t-2}$ is the logarithm of the Bayesian corruption index of recipient $i$ at time $t-2 ; D E M_{i, t-2}$ is the democracy level of recipient $i$ at time $t-2 ; B C I_{j, t-2}$ is the logarithm of the corruption perception index of donor $j$ at time $t-2 ; \boldsymbol{X}_{i, t-2}$ is the vector of the control variables; and $\varepsilon_{i, t}$ is the error term. The vector of the control variables, $\boldsymbol{X}$, includes: 1$)$ the ratio of the donor $j$ s GDP to the recipient is ( $G D P_{j} / G D P_{i}$ denoted by GDPRATIO); 2 ) the logarithm of the recipient's population size $\left.\left(P O P_{i}\right) ; 3\right)$ a dummy variable $C C V_{i}$ for the existence of civil conflict in the recipient country $i$ (with a value of 1 if there is a civil conflict and 0 otherwise); 4) a dummy variable $T E R_{i}$ for the existence of terrorist action in the recipient country.

We assume that the decision to provide aid to a country in year $t$ is made in time $t-1$ based on the explanatory variables observed at $t-2$. Shifting the independent variables backwards in time considers the information that was avail-

${ }^{9}$ See https://www.start.umd.edu/data-tools/global-terrorism-database-gtd. 
able to decision-makers at the time the aid was allocated. It also solves issues of simultaneity and information delays, eliminates the endogeneity problem (Amusa et al., 2016), and adds accuracy to the donors' decisions (Lopez, 2015).

One of the main issues with the available literature is related to the identification of the date of actual aid allocation decision. In fact, committed aid can extend over several years depending on the program length, and it is possible for a new program to start while another is still ongoing. As a result, it is essential to have an idea of when a recent allocation decision (increase or decrease of assistance level) is made. We postulate that a minimum of $25 \%$ variation (increase or decrease of $25 \%$ or more) in the total committed aid of year $t$ relative to the previous year is an indication of an actual decision by the donors. Our selection of the $25 \%$ threshold of the annual growth rate of the committed ODA is based on the observations in the sample period and on the fact that an increase/decrease of that magnitude is very likely to indicate a new allocation decision. For a robustness check, we later examine $10 \%$ and $50 \%$ thresholds.

Like Saibu and Obioesio (2017), we use a linear logarithmic transformation of the variables other than the dummies, allowing the estimated coefficients to be interpreted in terms of elasticities. Following the method used by Hansen and Tarp (2001), we add " 1 " to each variable containing the value " 0 " to capture this value even after the logarithmic transformation of the variables. To estimate the model, we use the robust version of the quantile regression proposed by Koenker and Basset (1978) and Koenker (2005). This method accounts for the entire conditional distribution of the dependent variable rather than just its average, as it is the case in linear regression. It is the most appropriate method to deal with the outliers in the dependent variable (ODA) and the heterogeneous nature of the recipient countries in our sample.

We test the robustness of our results by changing the dependent variable to aid per capita. The use of the ODA per capita is advocated by some authors (Thiele et al., 2007; Clist, 2009; Annen \& Kosempel, 2009) who argue that it eliminates the bias against less-populated countries. With the aid per capita, we run the following regression:

$$
\begin{aligned}
\text { ODA_PC } C_{i, j, t}= & \alpha_{i}+\beta_{1} G D P_{i, t-2}+\beta_{2} E X P_{j, i, t-2}+\beta_{3} D I S T_{j, i}+\beta_{4} B C I_{i, t-2} \\
& +\beta_{5} D E M_{i, t-2}+\beta_{6} B C I_{j, t-2}+\Upsilon X_{i, t-2}+\varepsilon_{i, t}
\end{aligned}
$$

where ODA_PC $C_{i, j, t}$ is the logarithm of 1 plus the per capita aid committed to recipient $i$ by donor $j$ at time $t$. All other variables are as previously defined. With this specification, the recipient's population size variable $\left(P O P_{i}\right)$ is dropped from the control variables.

\section{Empirical Results}

We analyze the donors' behavior towards those recipients most likely to receive aid from them. These recipients vary from one donor to another: the former colonies for France and the U.K., the English-speaking countries for the U.S. In 
Appendix A, the list of the 82 recipients' countries is provided along with their respective donors. Table 1 displays the descriptive statistics by donor country over the 2000-2014 period for ODA, with two-year lags for the explanatory and control variables.

On average, France provides the highest ODA per recipient country, followed by the U.S. There is a very high dispersion of the ODA, which justifies our choice of using the quantile regression model with the median since the regression estimates are more robust against outliers. The average and the range of GDP variables reveal that China's ODA is allocated to recipient countries that are less wealthy and have much greater needs than those of the U.K., the U.S., and France. Furthermore, the ratio of the Chinese GDP to its recipients' ( $\mathrm{GDP}_{\mathrm{RATIO}}$ ) is generally lower than that of the traditional donors. This is an indication that to reduce inequality, China provides aid to countries in need even though its own level of development is not much higher. The Bayesian Corruption Index is on average higher for recipients of Chinese aid, although the country with the highest level of corruption is among the recipients of French aid. While France and China provide aid to countries where they have commercial interests measured by their exports, there is at least one U.S. and one U.K. aid recipient country that does not import any products from their donor.

The empirical results presented in Table 2 show that several factors determine the variation of $25 \%$ or more in aid committed by donor countries. The determinants differ by the donor and include the recipient's needs and merits, as well as the donor's interests.

The first striking result in Table 2 reveals that the impact of the GDP of recipient countries-a measure of their needs-on the allocated aid is significant only for France and the U.S. Although the goal of ODA is to reduce poverty in the world and to lessen inequality between Northern and Southern countries, neither China nor the U.K. seems to tailor their aid to the achievement of this goal. This may bring into question the effectiveness of ODA, as has been suggested by many authors, including Bourguignon and Platteau (2017) and Briggs (2017). The recipient GDP is a significant determinant of the aid allocation decision by France and the U.S., but this result can also be interpreted as these donors' tendency to reward recipients with economic growth rather than supporting those in need (Hoeffler \& Outram, 2011).

We find a positive and significant relationship between the committed aid by France and the U.K. and the Bayesian corruption perception index (BCI) of their recipient countries: the amount of aid allocated by France and the U.K. increases to their former colonies with a higher level of corruption. As asserted by Doig and Theobald (2013), this situation can severely compromise the effectiveness of aid to the former colonies. The result can also indicate that part of the aid allocated by France and the U.K. serves to combat corruption and to implement sound governance in their former colonies. For China, a high score of the recipient corruption index has a negative impact on aid, but the relationship is not 
Table 1. Descriptive statistics.

\begin{tabular}{|c|c|c|c|c|c|c|c|c|c|c|c|c|}
\hline \multirow[b]{2}{*}{ Variable } & \multicolumn{6}{|c|}{ China } & \multicolumn{6}{|c|}{ United States } \\
\hline & $\mathbf{N}$ & Mean & $\begin{array}{l}\text { Standard } \\
\text { deviation }\end{array}$ & Min. & Max. & Median & $\mathrm{N}$ & Mean & $\begin{array}{l}\text { Standard } \\
\text { deviation }\end{array}$ & Min. & Max. & Median \\
\hline ODA & 184 & 15.00 & 5.41 & - & 21.34 & 16.54 & 348 & 15.47 & 4.75 & - & 21.28 & 16.93 \\
\hline ODA_PC & 184 & 1.08 & 1.14 & - & 5.60 & 0.67 & 348 & 1.74 & 1.41 & - & 7.46 & 1.58 \\
\hline GDP & 184 & 6.51 & 0.58 & 4.69 & 7.45 & 6.60 & 348 & 7.67 & 1.15 & 5.25 & 9.82 & 7.79 \\
\hline $\mathrm{BCI}$ & 184 & 4.08 & 0.08 & 3.85 & 4.20 & 4.10 & 348 & 3.88 & 0.20 & 3.36 & 4.17 & 3.91 \\
\hline DEM & 184 & 1.71 & 0.62 & 1 & 3 & 2 & 348 & 2.21 & 0.76 & 1 & 3 & 2 \\
\hline EXP & 184 & 18.46 & 1.93 & 13.25 & 22.34 & 18.65 & 348 & 18.08 & 2.89 & - & 23.87 & 17.92 \\
\hline DIST & 184 & 9.07 & 0.37 & 8.12 & 9.43 & 9.18 & 348 & 9.10 & 0.54 & 7.75 & 9.63 & 9.36 \\
\hline POP & 184 & 16.52 & 0.84 & 14.09 & 17.70 & 16.75 & 348 & 14.94 & 2.34 & 11.15 & 20.96 & 14.70 \\
\hline $\mathrm{CCV}$ & 184 & 0.22 & 0.41 & - & 1 & - & 348 & 0.12 & 0.32 & - & 1 & - \\
\hline TER & 184 & 0.52 & 0.50 & - & 1 & 1.00 & 348 & 0.31 & 0.46 & - & 1 & - \\
\hline $\mathrm{BCI}_{\mathrm{DON}}$ & 184 & 3.89 & 0.01 & 3.87 & 3.89 & 3.89 & 348 & 3.52 & 0.04 & 3.48 & 3.59 & 3.50 \\
\hline $\mathrm{GDP}_{\text {RATIO }}$ & 184 & 1.46 & 0.63 & 0.25 & 3.20 & 1.44 & 348 & 3.10 & 1.15 & 0.90 & 5.47 & 2.96 \\
\hline \multirow[b]{2}{*}{ Variable } & \multicolumn{6}{|c|}{ France } & \multicolumn{6}{|c|}{ United Kingdom } \\
\hline & $\mathbf{N}$ & Mean & $\begin{array}{l}\text { Standard } \\
\text { deviation }\end{array}$ & Min. & Max. & Median & $\mathbf{N}$ & Mean & $\begin{array}{l}\text { Standard } \\
\text { deviation }\end{array}$ & Min. & Max. & Median \\
\hline ODA & 301 & 17.25 & 2.67 & - & 21.14 & 17.75 & 376 & 14.66 & 4.21 & - & 21.81 & 15.29 \\
\hline ODA_PC & 301 & 2.25 & 1.28 & -1.90 & 5.96 & 2.18 & 376 & 1.01 & 0.91 & -0.03 & 4.56 & 0.73 \\
\hline GDP & 301 & 7.29 & 1.08 & 5.60 & 9.39 & 7.00 & 376 & 7.76 & 1.09 & 4.69 & 9.82 & 7.80 \\
\hline $\mathrm{BCI}$ & 301 & 3.98 & 0.19 & 3.48 & 4.22 & 4.05 & 376 & 3.89 & 0.21 & 3.36 & 4.20 & 3.94 \\
\hline DEM & 301 & 1.89 & 0.79 & 1 & 3 & 2 & 376 & 2.20 & 0.74 & 1 & 3 & 2 \\
\hline EXP & 301 & 18.67 & 1.93 & 14.17 & 22.43 & 18.97 & 376 & 17.68 & 2.39 & - & 22.88 & 17.74 \\
\hline DIST & 301 & 8.59 & 0.49 & 7.20 & 9.70 & 8.53 & 376 & 8.90 & 0.36 & 7.65 & 9.72 & 8.89 \\
\hline POP & 301 & 15.42 & 1.77 & 11.15 & 18.29 & 16.04 & 376 & 15.08 & 2.53 & 9.19 & 20.94 & 15.06 \\
\hline $\mathrm{CCV}$ & 301 & 0.10 & 0.30 & - & 1 & - & 376 & 0.13 & 0.33 & - & 1 & - \\
\hline TER & 301 & 0.27 & 0.44 & - & 1 & - & 376 & 0.32 & 0.47 & - & 1 & - \\
\hline $\mathrm{BCI}_{\mathrm{DON}}$ & 301 & 3.42 & 0.03 & 3.39 & 3.49 & 3.40 & 376 & 3.28 & 0.04 & 3.24 & 3.33 & 3.25 \\
\hline $\mathrm{GDP}_{\text {RATIO }}$ & 301 & 3.31 & 1.08 & 1.24 & 4.99 & 3.58 & 376 & 2.79 & 1.09 & 0.66 & 5.74 & 2.77 \\
\hline
\end{tabular}

ODA is the logarithm of 1 plus the annual official development aid committed by each donor to its recipients; ODA_PC is the logarithm of 1 plus the per capita aid committed to a recipient; GDP is the logarithm of the recipient gross domestic product; BCI is the logarithm of the recipient corruption perception index; DEM is the recipient democracy level; EXP is the logarithm of 1 plus the donor's exports to the recipient country; DIST is the logarithm of the distance between the donor and recipient capital cities; POP is the logarithm of the recipient's population size; CCV is the indicator of the existence of civil conflict in the recipient country; TER is the indicator of the existence of terrorist acts in the recipient country; $\mathrm{BCI}_{\mathrm{DON}}$ is the donor's Bayesian corruption perception index; and GDP $\mathrm{RATIO}_{\text {is }}$ ise logarithm of the ratio of the donor's GDP to the recipient. N is the number of recipient countries times the number of years where there is a year-over-year variation of $25 \%$ or more in the official development aid. Data are from 2000 to 2014 for the ODA with two-year lags for the other variables. 
Table 2. Determinants of aid allocation-results of the base-case analysis.

\begin{tabular}{|c|c|c|c|c|}
\hline Variables & China & United States & France & United Kingdom \\
\hline \multirow{2}{*}{ GDP } & 2.100 & $11.900^{*}$ & $5.319^{*}$ & -2.811 \\
\hline & $(1.40)$ & $(2.29)$ & $(2.04)$ & $(-1.08)$ \\
\hline \multirow{2}{*}{$\mathrm{BCI}$} & -4.364 & 0.442 & $1.504^{\star \star}$ & $2.713^{* * *}$ \\
\hline & $(-1.26)$ & $(0.45)$ & $(2.87)$ & $(3.50)$ \\
\hline \multirow{2}{*}{ DEM } & -0.578 & 0.088 & 0.047 & 0.294 \\
\hline & $(-1.25)$ & $(0.35)$ & $(0.46)$ & $(1.55)$ \\
\hline \multirow{2}{*}{ EXP } & 0.373 & -0.153 & $0.666^{* * *}$ & $0.891^{\star * *}$ \\
\hline & $(1.29)$ & $(-1.74)$ & (9.65) & $(8.54)$ \\
\hline \multirow{2}{*}{ DIST } & 0.147 & -0.643 & 0.176 & 0.712 \\
\hline & $(0.19)$ & $(-1.60)$ & $(0.82)$ & $(1.66)$ \\
\hline \multirow{2}{*}{ POP } & -0.113 & $1.247^{\star * *}$ & $0.216^{* * *}$ & -0.031 \\
\hline & $(-0.24)$ & $(9.26)$ & $(3.76)$ & $(-0.28)$ \\
\hline \multirow{2}{*}{$\mathrm{CCV}$} & -0.140 & -0.584 & -0.147 & -0.146 \\
\hline & $(-0.18)$ & $(-0.95)$ & $(-0.60)$ & $(-0.36)$ \\
\hline \multirow{2}{*}{ TER } & -0.210 & 0.502 & 0.060 & 0.282 \\
\hline & $(-0.36)$ & $(1.12)$ & $(0.35)$ & $(0.86)$ \\
\hline \multirow{2}{*}{$\mathrm{BCI}_{\mathrm{DON}}$} & 14.490 & 1.063 & $-5.681^{*}$ & $-7.635^{\star}$ \\
\hline & $(0.32)$ & $(0.20)$ & $(-2.37)$ & $(-2.08)$ \\
\hline \multirow{2}{*}{$\mathrm{GDP}_{\text {RATIO }}$} & 1.629 & $12.070^{\star}$ & $5.535^{\star}$ & -1.178 \\
\hline & $(1.25)$ & $(2.33)$ & $(2.13)$ & $(-0.45)$ \\
\hline \multirow{2}{*}{ Intercept } & -43.04 & $-128.20^{\star *}$ & -43.54 & 32.38 \\
\hline & $(-0.24)$ & $(-2.78)$ & $(-1.74)$ & $(1.33)$ \\
\hline $\mathrm{N}$ & 184 & 348 & 301 & 376 \\
\hline
\end{tabular}

Equation (1) estimation results where the dependent variable is the total committed aid (the logarithm of 1 plus the total aid committed to recipient $\mathrm{i}$ by donor $\mathrm{j}$ in year $t$ ) with a $25 \%$ year-over-year variation threshold. The explanatory variables (all taken in year $t-2$ ) are: GDP (the logarithm of the recipient gross domestic product); BCI (the logarithm of the recipient corruption perception index); DEM (the recipient democracy level); EXP (the logarithm of 1 plus the donor's exports to the recipient country); DIST (the logarithm of the distance between the donor and recipient capital cities); and $\mathrm{BCI}_{\mathrm{DON}}$ (the donor's Bayesian corruption perception index); the control variables include GDP $_{\text {RATIO }}$ (the logarithm of the ratio of the donor's GDP to the recipient); POP (the logarithm of the recipient's population size); $\mathrm{CCV}$ (the indicator of the existence of civil conflict in the recipient country); and TER (the indicator of the existence of terrorist acts in the recipient country). The estimation uses the robust version of the quantile regression with the median. The ODA sample span the 2000-2014 period. $t$-statistics are in parentheses. ${ }^{*},{ }^{* *}$, and ${ }^{* * *}$ indicate significance at $10 \%, 5 \%$, and $1 \%$ levels, respectively. 
significant. This result suggests that China, as an emerging donor, does not necessarily exhibit the same complacency that France and the U.K. may have towards their former colonies where corruption and misuse of public power for private gain can be prevalent. However, for France and the U.K., the quality of their own institutions measured by the level of corruption significantly affects their aid.

France and the U.K. are the donors for whom economic interests, measured by the level of exports to the recipient countries, are significant determinants of the committed aid. Our results confirm those of Zanger (2000), showing that France and the U.K. maintain good relations with their former colonies through trade and culture. As an indication of the less selfish economic interests of China and the United States, their aids are not significantly linked to their exports to the recipient countries.

The results show that American and French official development assistance aims at alleviating inequalities. The positive and significant coefficient of GDP $\mathrm{RATIO}_{\mathrm{O}}$ is an indication that these donors grant more aid to countries with a GDP that is much lower than theirs. They also put their focus on the most populated countries, providing more aid to highly populated recipients. In contrast, the results clearly indicate the absence of conditionality in the allocation of Chinese aid: it is not significantly related either to the beneficiaries' needs or to the variables associated with the reform required by various forums and declarations like those of Paris in 2005 and Accra in 2008.

Although favorable conditions in the recipient country, such as stability, absence of terrorist acts and civil conflicts are essential for aid to be effective, none of the four main donors seem to account for them significantly. Rewarding stability or reducing the risk of civil conflict (CCV) and fighting terrorism (TER), especially in nearby recipient countries (DIST), are not among the significant determinants of aid allocation.

For the robustness test analysis, we estimate Equation (2), where the dependent variable is the ODA per capita, and the control variables exclude the population size of the recipient countries ${ }^{10}$. The results do not differ materially from those of our main model in Table 2, especially for China and the U.S. For instance, the study reveals that the aid allocation practice in China is not affected by the four major potential determinants, namely, recipient needs, recipient merits, donor interest, and donor quality. The results also confirm that the U.S. is concerned by the recipient's needs since both the recipient's GDP and the ratio of the donor's GDP to the recipient remain the main determinants of the U.S. per capita aid allocation. After accounting for the recipient country population, France pursues its economic interests in granting aid to its former colonies. For the U.K., the level of democracy of the recipient countries and their internal security indicator appears to be significant determinants of ODA per capita. The results also substantiate the findings that France and the U.K. are committing

${ }^{10}$ The results are available upon request. 
even more aid to their former colonies with a higher level of corruption.

It is essential to investigate whether there is any shift over time in the aid allocation practices either by China to align its approach to those of the traditional donors or by any of the other traditional donors in response to the growing influence of emerging donors. For that purpose, we proceed by estimating Equation (1) over two subsamples arising from splitting our sample period into two parts. The first half, denoted by Period 1, runs from 2000 to 2007 while Period 2 is from 2008 to 2014 . The results are displayed in Table $3^{11}$.

There is no difference between the results for China over the two subperiods, while those of the three traditional donors reveal some substantive shifts in the determinants of their aid allocation. Indeed, none of the usual determinants of aid allocation is significant in both subperiods for China. Despite various criticisms of China's approach, this donor stands firm and does not try to change its practices to conform to other donors' approaches. For the three major traditional donors, there are some noticeable changes. For example, while France considers the recipient needs and the level of corruption of the recipient countries in the first half period, only economic interests measured by the export variable remain a significant determinant of its assistance in the second half period. It is also the case for the United States, where economic interests (export variable), as well as the level of corruption (BCI), have become the main determinants of aid in the second half period. The importance of the corruption variable in the latter half period may be related to the international context, such as the various recommendations arising from the declaration of Paris in 2005, Accra in 2008 and the Busan Forum in 2011. Unlike China, all the three major traditional donors consider their economic interests in the allocation of aid over the second subperiod.

Our main results are based on a $25 \%$ year-over-year variation in the total committed aid as an indicator of a new aid allocation decision. For the robustness check, we consider both a fewer $10 \%$ and a higher $50 \%$ threshold for sensitivity analysis. The results displayed in Table 4 are not qualitatively different from those of the main case (Table 2).

Indeed, none of the explanatory variables are statistically significant determinants of the Chinese aid allocation at the two alternative threshold levels, supporting the results from Dreher et al. (2018) that Chinese ODA is driven primarily by foreign policy considerations not accounted for by the usual determinants. While the GDP growth, the level of export to the recipient countries, the distance variable, and the GDP ratio are significant determinants of at least 10\% variation on the total committed aid by the United States, these variables are no longer significant in explaining a vast $50 \%$ or higher variation. Only the GDP growth and GDP ratio for France and the donor's corruption index for the U.K. exhibit the same features. It is worth pointing out that from the 191 instances of ${ }^{11}$ Given the relative stability of the donors' Bayesian corruption perception index over each subperiod, this variable is dropped from the analysis. 
Table 3. Determinants of aid allocation-results of the subsample analysis.

\begin{tabular}{|c|c|c|c|c|c|c|c|c|}
\hline \multirow[b]{2}{*}{ Variables } & \multicolumn{2}{|c|}{ China } & \multicolumn{2}{|c|}{ United States } & \multicolumn{2}{|c|}{ France } & \multicolumn{2}{|c|}{ United Kingdom } \\
\hline & $\begin{array}{c}\text { Period } \\
1\end{array}$ & $\begin{array}{c}\text { Period } \\
2\end{array}$ & $\begin{array}{c}\text { Period } \\
1\end{array}$ & $\begin{array}{l}\text { Period } \\
\quad 2\end{array}$ & $\begin{array}{c}\text { Period } \\
1\end{array}$ & $\begin{array}{l}\text { Period } \\
2\end{array}$ & $\begin{array}{c}\text { Period } \\
1\end{array}$ & $\begin{array}{c}\text { Period } \\
2\end{array}$ \\
\hline \multirow{2}{*}{ GDP } & 2.012 & -0.154 & 6.278 & 17.540 & $12.990^{* *}$ & 4.403 & -2.438 & \\
\hline & $(0.36)$ & $(-0.07)$ & $(0.84)$ & $(0.93)$ & $(2.86)$ & $(0.49)$ & $(-0.63)$ & $(-0.67)$ \\
\hline \multirow{2}{*}{ BCI } & -9.235 & 3.711 & -0.938 & $3.916^{*}$ & $2.445^{\star \star \star}$ & 0.809 & 1.783 & $3.158^{\star * *}$ \\
\hline & $(-$ & $(0.74)$ & $(-c$ & $(2.44)$ & $(3.56)$ & $(0.91)$ & (1.65) & $(3.75)$ \\
\hline \multirow{2}{*}{ DEM } & -0.009 & -0.727 & -0.288 & 0.491 & -0.047 & 0.043 & $1.082^{* * *}$ & $-0.438^{\star}$ \\
\hline & .01) & $(-$ & & $(1.05)$ & 4) & $(0.26)$ & $(4.22)$ & 3) \\
\hline \multirow{2}{*}{ EXP } & -0.064 & 0.869 & 0.019 & $-0.319^{\star}$ & $0.529^{* * *}$ & $0.770^{* * *}$ & $0.683^{* * *}$ & $0.853^{* * *}$ \\
\hline & $(-0.08)$ & $(1.94)$ & $(0.15)$ & & $(6.08)$ & $(6.40)$ & $(3.44)$ & $(8.31)$ \\
\hline \multirow{2}{*}{ DIST } & -0.111 & 1.195 & $-1.140^{*}$ & -0.160 & -0.117 & 0.301 & 0.039 & 0.548 \\
\hline & $(-0.05)$ & $(1.08)$ & $(-2.34)$ & $(-0.25)$ & & $(0.79)$ & $(0.06)$ & (1.17) \\
\hline \multirow{2}{*}{ POP } & 0.648 & -0.696 & $1.210^{\star * *}$ & $1.314^{\star * *}$ & $0.292^{\star * *}$ & 0.056 & -0.025 & 0.094 \\
\hline & $(0.52)$ & $(-1.00)$ & $(7.09)$ & $(6.23)$ & $(4.33)$ & $(0.53)$ & $(-0.14)$ & $(0.81)$ \\
\hline \multirow{2}{*}{$\mathrm{CCV}$} & 0.193 & -0.308 & -0.276 & -2.012 & -0.348 & 0.081 & -0.614 & 0.080 \\
\hline & $(0.09)$ & $(-0.27)$ & $(-0.44)$ & $(-1.62)$ & $(-1.24)$ & $(0.16)$ & $(-1.13)$ & $(0.17)$ \\
\hline \multirow{2}{*}{ TER } & 0.973 & -0.902 & 0.237 & 0.701 & -0.250 & 0.111 & 0.538 & -0.425 \\
\hline & $(0.60)$ & $(-1.03)$ & $(0.49)$ & $(0.87)$ & $(-1.04)$ & $(0.39)$ & $(1.20)$ & $(-1.11)$ \\
\hline \multirow{2}{*}{$\mathrm{GDP}_{\text {RATIO }}$} & 1.188 & -0.208 & 6.694 & 17.240 & $13.040^{\star *}$ & 4.797 & -0.516 & -2.479 \\
\hline & $(0.22)$ & $(-0.11)$ & $(0.90)$ & $(0.92)$ & $(2.87)$ & $(0.54)$ & $(-0.13)$ & $(-0.43)$ \\
\hline \multirow{2}{*}{ Intercept } & 30.06 & -10.85 & -56.77 & -200.70 & $-142.9^{\star *}$ & -51.82 & 14.23 & 19.48 \\
\hline & $(0.52)$ & $(-0.39)$ & $(-0.71)$ & $(-0.99)$ & $(-2.98)$ & $(-0.55)$ & $(0.35)$ & $(0.31)$ \\
\hline $\mathrm{N}$ & 81 & 103 & 155 & 193 & 127 & 174 & 145 & 231 \\
\hline
\end{tabular}

Equation (1) estimation results where the dependent variable is the total committed aid (the logarithm of 1 plus the total aid committed to recipient $i$ by donor $\mathrm{j}$ in year $t$ ) for two subperiods. Period 1 runs from 2000 to 2007 while Period 2 is from 2008 to 2014 for the dependent variable. All the explanatory variables (all taken in year $t-2$ ) are as defined in Table 2. The estimation uses the robust version of the quantile regression with the median. The sample covers 15 recipient countries for China, 45 for the U.S., 33 for France, and 45 for the U.K. $t$-statistics are in parentheses. ${ }^{*},{ }^{* *}$, and ${ }^{* *}$ indicate significance at $10 \%, 5 \%$, and $1 \%$ levels, respectively.

at least $10 \%$ variation of committed Chinese aid, $89 \%$ are related to substantial shifts of at least $50 \%$. This ratio is only $46 \%$ for the United States, $47 \%$ for France, and 54\% for the United Kingdom. 
Table 4. Determinants of aid allocation—results of the sensitivity analysis.

\begin{tabular}{|c|c|c|c|c|c|c|c|c|}
\hline \multirow{2}{*}{ Variables } & \multicolumn{2}{|c|}{ China } & \multicolumn{2}{|c|}{ United States } & \multicolumn{2}{|c|}{ France } & \multicolumn{2}{|c|}{ United Kingdom } \\
\hline & $10 \%$ & $50 \%$ & $10 \%$ & $50 \%$ & $10 \%$ & $50 \%$ & $10 \%$ & $50 \%$ \\
\hline \multirow{2}{*}{ GD } & 0.427 & 1.625 & 12.3 & 6.238 & $4.834^{\star}$ & 5.312 & -0.889 & -2.4 \\
\hline & $(0.30)$ & $(1.01)$ & $(2.94)$ & $(0.76)$ & $(2.42)$ & $(1.32)$ & $(-0.41)$ & $(-0.71)$ \\
\hline \multirow{2}{*}{ BCI } & -1.680 & -4.463 & 0.547 & 1.573 & $1.052^{\star}$ & $1.786^{*}$ & $2.846^{* * *}$ & $2.047^{\star}$ \\
\hline & $(-0.52)$ & $(-1.17)$ & $(0.69)$ & $(0.96)$ & $(2.51)$ & $(2.42)$ & $(4.20)$ & $(2.11)$ \\
\hline \multirow{2}{*}{ DEM } & 0.0267 & -0.770 & 0.201 & -0.260 & -0.110 & 0.0269 & 0.319 & 0.428 \\
\hline & $(0.06)$ & $(-1.51)$ & $(0.97)$ & $(-0.63)$ & $(-1.35)$ & $(0.17)$ & $(1.97)$ & $(1.84)$ \\
\hline \multirow{2}{*}{ EXP } & 0.389 & 0.535 & $-0.318^{* * *}$ & -0.0212 & $0.641^{* * *}$ & $0.723^{\star * *}$ & $0.852^{\star * \star}$ & $1.001^{\star * *}$ \\
\hline & $(1.43)$ & $(1.71)$ & $(-5.38)$ & $(-0.14)$ & $(11.64)$ & $(7.38)$ & $(9.20)$ & $(8.22)$ \\
\hline \multirow{2}{*}{ DIST } & 0.00318 & 0.646 & $-0.650^{\star}$ & -0.378 & 0.0266 & 0.269 & 0.573 & 0.919 \\
\hline & $(0.00)$ & $(0.76)$ & $(-2.06)$ & $(-0.60)$ & $(0.16)$ & $(0.86)$ & $(1.54)$ & $(1.76)$ \\
\hline \multirow{2}{*}{ POP } & 0.00785 & -0.519 & $1.200^{* * *}$ & $1.165^{\star \star *}$ & $0.178^{\star * *}$ & $0.284^{* * *}$ & -0.0389 & -0.0466 \\
\hline & $(0.02)$ & $(-1.03)$ & (11.70) & (5.11) & (3.83) & (3.43) & $(-0.40)$ & $(-0.35)$ \\
\hline \multirow{2}{*}{$\mathrm{CCV}$} & 0.425 & -0.256 & -0.458 & -0.372 & -0.154 & -0.254 & -0.00160 & 0.0986 \\
\hline & $(0.58)$ & $(-0.31)$ & $(-0.94)$ & $(-0.37)$ & $(-0.80)$ & $(-0.68)$ & $(-0.00)$ & $(0.19)$ \\
\hline \multirow{2}{*}{ TER } & -0.515 & -0.265 & $0.868^{\star}$ & 0.260 & -0.117 & -0.0322 & 0.235 & 0.291 \\
\hline & $(-0.92)$ & $(-0.42)$ & (2.39) & $(0.36)$ & $(-0.83)$ & $(-0.12)$ & $(0.85)$ & $(0.72)$ \\
\hline \multirow{2}{*}{$\mathrm{BCI}_{\mathrm{DON}}$} & -62.02 & -7.004 & 1.756 & 1.196 & $-4.880^{*}$ & $-9.435^{\star *}$ & $-9.422^{\star *}$ & -4.478 \\
\hline & $(-1.44)$ & $(-0.14)$ & $(0.41)$ & $(0.14)$ & $(-2.47)$ & $(-2.67)$ & $(-2.92)$ & $(-1.00)$ \\
\hline \multirow{2}{*}{$\mathrm{GDP}_{\text {RATIO }}$} & -0.0916 & 1.263 & $12.31^{\star \star}$ & 6.706 & $5.154^{\star}$ & 5.463 & 0.706 & -0.524 \\
\hline & $(-0.07)$ & $(0.91)$ & $(2.94)$ & $(0.82)$ & $(2.58)$ & $(1.36)$ & $(0.32)$ & $(-0.15)$ \\
\hline \multirow{2}{*}{ Intercept } & 254.6 & 44.16 & $-131.4^{\star * *}$ & -76.24 & -37.07 & -34.22 & 19.50 & 16.01 \\
\hline & $(1.47)$ & $(0.22)$ & $(-3.55)$ & $(-1.06)$ & $(-1.94)$ & $(-0.88)$ & $(0.96)$ & $(0.50)$ \\
\hline $\mathrm{N}$ & 191 & 170 & 471 & 218 & 395 & 186 & 465 & 253 \\
\hline
\end{tabular}

Equation (1) estimation results where the dependent variable is the total committed aid (the logarithm of 1 plus the total aid committed to recipient $i$ by donor $j$ in year $t$ ) for $10 \%$ and $50 \%$ year-over-year variation thresholds. All the explanatory variables are as defined in Table 2. The sample covers 15 recipient countries for China, 45 for the U.S., 33 for France, and 45 for the U.K. t-statistics are in parentheses. ${ }^{*}{ }^{* *}$, and ${ }^{* *}$ indicate significance at $10 \%, 5 \%$, and $1 \%$ levels, respectively.

\section{Conclusion}

The considerable increase in aid flows in recent years and the growing influence of many emerging donors, alongside traditional donors, make it essential to study the determinants of bilateral ODA allocation. Motivations for the study are heightened by the attractiveness of Chinese aid for recipients and a desire to under- 
stand the resulting behavior of traditional donors towards some specific beneficiaries. With specific donor-recipient combinations, we use a robust version of quantile regression with the median to counter issues related to outliners and heterogeneity. We consider that a new aid allocation decision results in a variation of at least $25 \%$ in the allocated aid.

We find that the determinants of bilateral ODA differ widely from one donor country to another. For instance, the study reveals that the Chinese aid allocation is not influenced by the four major potential determinants, namely, recipient needs, recipient merits, donor interests, and donor quality. This may hinder the effectiveness of Chinese aid. The results also indicate that France and the U.S. consider the recipient needs when allocating their ODA. Furthermore, France and the U.K. pursue their economic interests related to their exports in granting aid to their former colonies, even to those with higher corruption levels.

Given the critiques of Chinese practices, but also the attractiveness of Chinese aid to recipient countries, adjustments would be expected either from traditional donors or from China. However, we show that there is no material shift in the determinants of aid allocation by China over the 2000-2014 period. In contrast, the three major traditional donors seem to shift the determinants of their aid allocation towards their self-economic interests over the second half period of our analysis. Since data related to ODA allocation by China are limited in their length and scope even for this study, the investigation of the real motives of aid allocation by both emerging and traditional donors needs to be pursued further in other to understand the appropriate channel for aid to be fully effective. It is also left for future research to study the short- and long-term effectiveness of ODA from China in the recipient countries, compared to that of aid from traditional major donors.

\section{Conflicts of Interest}

The authors declare no conflicts of interest regarding the publication of this paper.

\section{References}

Alesina, A., \& Dollar, D. (2000). Who Gives Foreign Aid to Whom and Why? Journal of Economic Growth, 5, 33-63. https://doi.org/10.1023/A:1009874203400

Amusa, K., Monkam, N., \& Viegi, N. (2016). The Political and Economic Dynamics of Foreign Aid: A Case Study of United States and Chinese Aid to Sub-Sahara Africa. ERSA-Economic Research Southern Africa.

Annen, K., \& Kosempel, S. (2009). Foreign Aid, Donor Fragmentation, and Economic Growth. The BE Journal of Macroeconomics, 9, Article 33. https://doi.org/10.2202/1935-1690.1863

Asmus, G., Fuchs, A., \& Müller, A. (2017). Chapter 7. BRICS and Foreign Aid. In The Political Economy of the BRICS Countries (pp. 139-177). World Scientific Publishing. https://doi.org/10.1142/9789811202308_0007

Azam, J. P., \& Delacroix, A. (2006). Aid and the Delegated Fight against Terrorism. Re- 
view of Development Economics, 10, 330-344.

https://doi.org/10.1111/j.1467-9361.2006.00321.x

Bermeo, S. B. (2017). Aid Allocation and Targeted Development in an Increasingly Connected World. International Organization, 71, 735-766. https://doi.org/10.1017/S0020818317000315

Berthélemy, J. C. (2006). Bilateral Donors' Interest vs. Recipients' Development Motives in Aid Allocation: Do All Donors Behave the Same? Review of Development Economics, 10, 179-194. https://doi.org/10.1111/j.1467-9361.2006.00311.x

Berthélemy, J. C., \& Tichit, A. (2004). Bilateral Donors' Aid Allocation Decisions-A Three-Dimensional Panel Analysis. International Review of Economics \& Finance, 13, 253-274. https://doi.org/10.1016/j.iref.2003.11.004

Betzold, C., \& Weiler, F. (2018). The History and Political Economy of Adaptation Aid. In Development Aid and Adaptation to Climate Change in Developing Countries (pp. 21-55). Palgrave Macmillan. https://doi.org/10.1007/978-3-319-64510-0_2

Bourguignon, F., \& Platteau, J. P. (2017). Does Aid Availability Affect Effectiveness in Reducing Poverty? A Review Article. World Development, 90, 6-16.

https://doi.org/10.1016/j.worlddev.2015.06.003

Briggs, R. C. (2017). Does Foreign Aid Target the Poorest? International Organization, 71, 187-206. https://doi.org/10.1017/S0020818316000345

Broich, T. (2017). Do Authoritarian Regimes Receive More Chinese Development Finance than Democratic Ones? Empirical Evidence for Africa. China Economic Review, 46, 180-207. https://doi.org/10.1016/j.chieco.2017.09.006

Burnside, C., \& Dollar, D. (2004). Aid, Policies, and Growth: Reply. American Economic Review, 94, 781-784. https://doi.org/10.1257/0002828041464524

Carey, S. C. (2007). European Aid: Human Rights versus Bureaucratic Inertia? Journal of Peace Research, 44, 447-464. https://doi.org/10.1177/0022343307078938

Chong, A. E., \& Gradstein, M. (2011). Who's Afraid of Foreign Aid? The Donors' Perspective. IDB Publications (Working Papers) 1573. Inter-American Development Bank.

Chun, H. M., Munyi, E. N., \& Lee, H. (2010). South Korea as an Emerging Donor: Challenges and Changes on Its Entering OECD/DAC. Journal of International Development, 22, 788-802. https://doi.org/10.1002/jid.1723

Claessens, S., Cassimon, D., \& Van Campenhout, B. (2009). Evidence on Changes in Aid Allocation Criteria. The World Bank Economic Review, 23, 185-208. https://doi.org/10.1093/wber/lhp003

Clist, P. (2009). 25 Years of Aid Allocation Practice: Comparing Donors and Eras (No. 09/11). CREDIT Research Paper.

Clist, P. (2011). 25 Years of Aid Allocation Practice: Whither Selectivity? World Development, 39, 1724-1734. https://doi.org/10.1016/j.worlddev.2011.04.031

Crost, B., Felter, J., \& Johnston, P. (2014). Aid under Fire: Development Projects and Civil Conflict. American Economic Review, 104, 1833-1856. https://doi.org/10.1257/aer.104.6.1833

Dietrich, S. (2013). Bypass or Engage? Explaining Donor Delivery Tactics in Foreign Aid Allocation. International Studies Quarterly, 57, 698-712. https://doi.org/10.1111/isqu.12041

Doig, A., \& Theobald, R. (2013). Corruption and Democratization. Routledge. https://doi.org/10.4324/9781315039602

Dollar, D., \& Levin, V. (2006). The Increasing Selectivity of Foreign Aid, 1984-2003. World 
Development, 34, 2034-2046. https://doi.org/10.1016/j.worlddev.2006.06.002

Dreher, A., \& Fuchs, A. (2011). Does Terror Increase Aid? Public Choice, 149, 337. https://doi.org/10.1007/s11127-011-9878-8

Dreher, A., Fuchs, A., Parks, B., Strange, A. M., \& Tierney, M. J. (2018). Apples and Dragon Fruits: The Determinants of Aid and Other Forms of State Financing from China to Africa. International Studies Quarterly, 62, 182-194. https://doi.org/10.1093/isq/sqx052

Dreher, A., Fuchs, A., Parks, B., Strange, A., \& Tierney, M. J. (2017). Aid, China, and Growth: Evidence from a New Global Development Finance Dataset (61 p.). AidData Working Paper \#46. https://doi.org/10.2139/ssrn.3051044

Dreher, A., Klasen, S., Vreeland, J. R., \& Werker, E. (2013). The Costs of Favoritism: Is Politically Driven Aid Less Effective? Economic Development and Cultural Change, 62, 157-191. https://doi.org/10.1086/671711

Dreher, A., Nunnenkamp, P., \& Thiele, R. (2011). Are "New” Donors Different? Comparing the Allocation of Bilateral Aid between Non-DAC and DAC Donor Countries. World Development, 39, 1950-1968. https://doi.org/10.1016/j.worlddev.2011.07.024

Feeny, S., \& McGillivray, M. (2008). What Determines Bilateral Aid Allocations? Evidence from Time Series Data. Review of Development Economics, 12, 515-529. https://doi.org/10.1111/j.1467-9361.2008.00443.x

Goldstein, A., Pinaud, N., Reisen, H., \& Chen, X. (2006). The Rise of China and India: What's in It for Africa? OECD Development Centre Studies.

https://doi.org/10.1787/9789264024427-en

Hansen, H., \& Tarp, F. (2001). Aid and Growth Regressions. Journal of Development Economics, 64, 547-570. https://doi.org/10.1016/S0304-3878(00)00150-4

Hoeffler, A., \& Outram, V. (2008). What Determines the Allocation of Aid? The Centre for the Study of African Economies Working Paper Series, 299.

Hoeffler, A., \& Outram, V. (2011). Need, Merit, or Self-Interest-What Determines the Allocation of Aid? Review of Development Economics, 15, 237-250. https://doi.org/10.1111/j.1467-9361.2011.00605.x

Koch, D. J., Dreher, A., Nunnenkamp, P., \& Thiele, R. (2009). Keeping a Low Profile: What Determines the Allocation of Aid by Non-Governmental Organizations? World Development, 37, 902-918. https://doi.org/10.1016/j.worlddev.2008.09.004

Koenker, R. (2005). Quantile Regression. Cambridge University Press. https://doi.org/10.1017/CBO9780511754098

Koenker, R., \& Bassett, G. (1978). Regression Quantiles. Econometrica, 46, 33-50. https://doi.org/10.2307/1913643

Kragelund, P. (2008). The Return of Non-DAC Donors to Africa: New Prospects for African Development? Development Policy Review, 26, 555-584. https://doi.org/10.1111/j.1467-7679.2008.00423.x

Larmour, P. (2017). Governance and Reform in the South Pacific. National Centre for Development Studies, Research School of Pacific Studies, The Australian National University.

Lopez, L. E. (2015). Corruption and International Aid Allocation: A Complex Dance. Journal of Economic Development, 40, 35. https://doi.org/10.35866/caujed.2015.40.1.002

Lundsgaarde, E., Breunig, C., \& Prakash, A. (2010). Instrumental Philanthropy: Trade and the Allocation of Foreign Aid. Canadian Journal of Political Science, 43, 733-761. 
https://doi.org/10.1017/S0008423910000661

Manning, R. (2006). Will "Emerging Donors" Change the Face of International Co-Operation? Development Policy Review, 24, 371-385. https://doi.org/10.1111/j.1467-7679.2006.00330.x

Mayer, T., \& Zignago, S. (2011). Notes on CEPII’s Distances Measures: The GeoDist Database. https://doi.org/10.2139/ssrn.1994531

Miller, D. C. (2014). Explaining Global Patterns of International Aid for Linked Biodiversity Conservation and Development. World Development, 59, 341-359. https://doi.org/10.1016/j.worlddev.2014.01.004

Neumayer, E. (2003a). Do Human Rights Matter in Bilateral Aid Allocation? A Quantitative Analysis of 21 Donor Countries. Social Science Quarterly, 84, 650-666. https://doi.org/10.1111/1540-6237.8403010

Neumayer, E. (2003b). The Determinants of Aid Allocation by Regional Multilateral Development Banks and United Nations Agencies. International Studies Quarterly, 47, 101-122. https://doi.org/10.1111/1468-2478.4701005

Nunnenkamp, P., \& Thiele, R. (2006). Targeting Aid to the Needy and Deserving: Nothing but Promises? World Economy, 29, 1177-1201. https://doi.org/10.1111/j.1467-9701.2006.00836.x

Paczynska, A. (2020). The New Politics of Aid: Emerging Donors and Conflict-Affected States. Lynne Rienner Publishers, Incorporated.

Rayp, G., \& Standaert, S. (2017). Measuring Actual Economic Integration: A Bayesian State-Space Approach. In Indicator-Based Monitoring of Regional Economic Integration (pp. 341-360). Springer. https://doi.org/10.1007/978-3-319-50860-3_16

Saibu, O., \& Obioesio, F. (2017). Foreign Aid, Fiscal Optimality and Economic Growth in Nigeria. SPOUDAI Journal of Economics and Business, 67, 85-99.

Schneider, C. J., \& Tobin, J. L. (2013). Interest Coalitions and Multilateral Aid Allocation in the European Union. International Studies Quarterly, 57, 103-114. https://doi.org/10.1111/isqu.12062

Schudel, C. J. W. (2008). Corruption and Bilateral Aid: A Dyadic Approach. Journal of Conflict Resolution, 52, 507-526. https://doi.org/10.1177/0022002708316646

Standaert, S. (2015). Divining the Level of Corruption: A Bayesian State-Space Approach. Journal of Comparative Economics, 43, 782-803. https://doi.org/10.1016/j.jce.2014.05.007

Strömberg, D. (2007). Natural Disasters, Economic Development, and Humanitarian Aid. Journal of Economic Perspectives, 21, 199-222. https://doi.org/10.1257/jep.21.3.199

Szent-Iványi, B. (2012). Aid Allocation of the Emerging Central and Eastern European Donors. Journal of International Relations and Development, 15, 65-89. https://doi.org/10.1057/jird.2011.19

Thiele, R., Nunnenkamp, P., \& Dreher, A. (2007). Do Donors Target Aid in Line with the Millennium Development Goals? A Sector Perspective of Aid Allocation. Review of World Economics, 143, 596-630. https://doi.org/10.1007/s10290-007-0124-X

Vreeland, J. R., \& Dreher, A. (2014). The Political Economy of the United Nations Security Council: Money and Influence. Cambridge University Press. https://doi.org/10.1017/CBO9781139027755

Wagner, D. (2003). Aid and Trade-An Empirical Study. Journal of the Japanese and International Economies, 17, 153-173. https://doi.org/10.1016/S0889-1583(03)00010-8

Weiler, F., Klöck, C., \& Dornan, M. (2018). Vulnerability, Good Governance, or Donor 
Interests? The Allocation of Aid for Climate Change Adaptation. World Development, 104, 65-77. https://doi.org/10.1016/j.worlddev.2017.11.001

Woods, N. (2008). Whose Aid? Whose Influence? China, Emerging Donors and the Silent Revolution in Development Assistance. International Affairs, 84, 1205-1221. https://doi.org/10.1111/j.1468-2346.2008.00765.x

Younas, J. (2008). Motivation for Bilateral Aid Allocation: Altruism or Trade Benefits. European Journal of Political Economy, 24, 661-674. https://doi.org/10.1016/j.ejpoleco.2008.05.003

Zanger, S. C. (2000). Good Governance and European Aid: The Impact of Political Conditionality. European Union Politics, 1, 293-317.

https://doi.org/10.1177/1465116500001003002 


\section{Appendix A. List of Recipient Countries by Donors}

\begin{tabular}{|c|c|c|c|}
\hline China & United States & France & United Kingdom \\
\hline Afghanistan & South Africa & Algeria & Afghanistan \\
\hline Burundi & $\begin{array}{c}\text { Antigua } \\
\text { and Barbuda }\end{array}$ & Benin & South Africa \\
\hline Cambodia & Barbados & Burkina Faso & Antigua and Barbuda \\
\hline Cameroon & Belize & Cambodia & Bahrain \\
\hline Eritrea & Botswana & Cameroon & Bangladesh \\
\hline Ghana & Cameroon & Central African Republic & Barbados \\
\hline Guinea-Bissau & Dominica & Comoros & Belize \\
\hline Kenya & Egypt & Congo & Bhutan \\
\hline Mozambique & Eritrea & Ivory Coast & Botswana \\
\hline Uganda & Ethiopia & Djibouti & Dominica \\
\hline $\begin{array}{c}\text { Papua } \\
\text { New Guinea }\end{array}$ & Fiji & Dominican Republic & Egypt \\
\hline Sudan & Gambia & Dominica & Eritrea \\
\hline Tanzania & Ghana & Gabon & Fiji \\
\hline Zambia & Grenade & Grenade & Gambia \\
\hline \multirow[t]{15}{*}{ Zimbabwe } & Guyana & Guinea & Ghana \\
\hline & $\begin{array}{l}\text { Solomon } \\
\text { Islands }\end{array}$ & Haiti & Grenade \\
\hline & India & Laos & Guyana \\
\hline & Jamaica & Lebanon & Solomon Islands \\
\hline & Jordan & Liberia & India \\
\hline & Kenya & Madagascar & Jamaica \\
\hline & Kiribati & Mali & Jordan \\
\hline & Lesotho & Morocco & Kenya \\
\hline & Lebanon & Mauritius & Kiribati \\
\hline & Liberia & Mauritania & Lesotho \\
\hline & Malawi & Niger & Malaysia \\
\hline & Malta & Senegal & Malawi \\
\hline & Mauritius & Seychelles & Maldives \\
\hline & $\begin{array}{c}\text { Micronesia } \\
\text { (Federated } \\
\text { States of) }\end{array}$ & Syria & Malta \\
\hline & Namibia & Chad & Mauritius \\
\hline
\end{tabular}




\section{Continued}

\begin{tabular}{ccc}
\hline Nigeria & Togo & Nigeria \\
Uganda & Tunisia & Uganda \\
Pakistan & Vanuatu & Pakistan \\
Papua New & Vietnam & Papua New Guinea \\
Guinea & & Seychelles \\
Philippines & & Sierra Leone \\
Rwanda & Sudan \\
Samoa & Sri Lanka \\
Seychelles & Swaziland \\
Sierra Leone & Tanzania \\
Swaziland & Tonga \\
Tanzania & Trinidad and Tobago \\
Tonga & Tuvalu \\
Trinidad & & Vanuatu \\
and Tobago & & Zambia \\
Zamuatu &
\end{tabular}

